\title{
Hydrops Layer with Communicating Hydrocephal- about a Case
}

\author{
Ligia Acosta Boett*1 and Teolinda Morales ${ }^{2}$ \\ ${ }^{1}$ Pediatrician Otorhinolaryngologist, Department of Otoneurology, Institute of Otorhinolaryngology, Venezuela \\ ${ }^{2}$ Medical Otorrinolaringólogo, Department of Otoneurology, Institute of Otorhinolaryngology, Venezuela
}

Submission: February 27, 2017; Published: March 09, 2017

*Corresponding author: Acosta Boett Ligia, Jefe de Servicio de Otorrinolaringología. Hospital de Niños “Dr. José Manuel de los Ríos”, icepresidenta de la Junta Directiva SVORL, Venezuela, South America, Email: ligiaorl2@gmail.com

\begin{abstract}
The Labyrinthine Hydrops is defined as the dilatation of the labyrinthine membranes associated with an increase of the endolaberinticos liquids, manifested by Vertigo, Tinnitus, Fullness Otica and Hearing Loss. Its etiology is unknown; However, endolymphatic duct obstruction and labyrinthine microhomostasis disorders have been considered responsible pathogenic factors. We present the case of a 28-year-old female patient with rotational, positional, seizure-like dizziness, with a 3-month course of concomitant nausea, bilateral tinnitus and constant headache. Integral Otoneurological study is performed which reveals: Bilateral labyrinthine irritability and Cerebral RSM with communicating global hydrocephalus. Peritoneal Ventricle Derivation is performed with resolution of Hydrocephalus and disappearance of the Vestibular Cocleo symptomatology.
\end{abstract}

\section{Clinical Case}

A 28-year-old female patient presented with a three-month rotational vertigo seizure with concomitant nausea, severe bilateral tinnitus, optic fullness and constant universal pulsating headache.

\section{Personal history}

I abort one [1] month before the start of EA

Family background:

No contributarions.

Physical examination: Positive Findings ORL:

Mucosa of pale inferior turbinates with slight hypertrophy.

Bilateral tympanic tumors with Positive Neumatoscopy bilaterally.

\section{Otoneurological study}

a) Clinical: Nystagmus positive to extreme gaze, gait test and Romberg Lateralization to the right.

b) Cochlear scan:

c) Tonal audiometry: Normal hearing

d) Vocal Audiometry: Good Bilateral Discrimination. e) Impedanciometry: Both curves deformation, pressure and normal amplitude.

f) Stapedial reflexes ipsi and contralateral present with evidence of bilateral recruitment.

g) Neural adaptation: Normal.

h) Rinne's test: positive (+) Bilateral. Weber Test: Indifferent

i) Electronystagmography: Nystagmus spontaneous and semispontaneous absent, Normal tract, Nystagmus Optokinetic present with correct sense

j) Rotatory Chair: presence of both vestibular systems, Caloric Tests: Nystagmus of high frequency to bilateral bithermal irrigation.

k) Otoneurological Conclusion: Normal Hearing. Bilateral labyrinthine irritability.

\section{Laboratory tests}

Hematology, Blood Chemistry, Cholesterol, Triglycerides, HIV, VDRL, EX. Urine, within normal limits.

\section{RSM Cerebral}

Global Hydrocephalus Communicant with slight Stenosis of the Silvio Aqueduct. 


\section{Driving}

It is evaluated jointly with Neurosurgery, suggesting Peritoneal Ventricle Derivation, it is intervened surgically obtaining a satisfactory resolution of hydrocephalus with disappearance of the cochleovestibular symptomatology. Currently 3 years postoperative, in control and follow-up, asymptomatic.

\section{Discussion}

Labyrinthine Hydrops is defined as the dilatation of labyrinthine membranes associated with an increase in endolaberinic fluid, clinically manifested by Vertigo, Tinnitus, Optical Plenitude, and can reach Hearing Loss. Its etiology is unknown. An origin has been postulated:

Embryopathic (Dysplasia of Mondini), Acquired (post infections, trauma, metabolic, endocrine, immunological, vascular disorders), Ideopathic (Meniere's disease). Mechanical obstruction of the endolymphatic duct and labyrinthine microhomostasis disorders have been considered as pathogenic factors responsible for Labyrinthine Hydrops [1-3]. The constant and balanced composition of the fluids of the inner ear are fundamental for the good functioning of the vestibular cochlea.

\section{Inner ear fluids play important roles}

a) Provide an appropriate and specific ionic environment for optimal generation of biopotentials necessary for proper inner ear function.

b) Keep the internal ear pressure balanced; The hydrostatic CSF variations are transmitted by the cochlear aqueduct to the perilymphatic spaces, simultaneously this pressure of the liquid is exerted on the walls of the endolymphatic sac, which causes the pressures to be equal on both sides of the Reissner membrane.

c) They allow the transportation of nutrient principles to the terminal organs and the elimination of metabolic waste products from the cochlea.

d) Medium of transmission of the vibrations that go from the stirrup to the energy transforming centers of the middle ear.

Fluids from the inner ear are in contact with the surrounding tissues, they communicate directly or indirectly with the CSF and / or blood, with a permanent exchange of ions and metabolites, due to the biochemical differences between them $[1,4]$. Intracranial pressure may modify the intralaberintic pressure directly by the Cochlear Aqueduct or indirectly by the labyrinthine branches of the intracranial vasculature, especially the microvenules [5,6]. The maintenance of microhomostasis of internal ear fluids depends on:

i. Energy-dependent ion pumps.

ii. Constant blood circulation.

\section{iii. LCR-Laberintic Barrier.}

There are several situations, conditions, or factors that may disturb maintenance of microhomostasis of endolaberinic fluids, leading to accumulation of ions, metabolites, excess fluid in the inner ear compartments, leading to osmotic imbalance, labyrinthine membrane distention And consequently functional disturbances of balance and hearing $[1,7,8]$. In the case described above, Global Communicating Hydrocephalus is considered to be the disturbing condition of microhomostasis of endolaberinic fluids, conditioning osmotic imbalance, labyrinthine membrane distention and Labyrinthine Hydrops.

\section{Conclusion}

In the discussion with Neurosurgery, it is suggested that the mild Stenosis of the Silvio Aqueduct (congenital malformation), until now had been adequately tolerated by the patient, since it allowed good management of cerebral fluid dynamics with adequate CSF flow and drainage, is unknown The cause of increased intracranial water volume (no positive history in the annanesis), responsible for communicating global hydrocephalus, because there is only limitation in the flow and drainage of the CSF, but no obstruction (Obstructive Hydrocephalus). It could be considered viral or immunological post-infectious etiology that caused fibrosis or adhesions of the arachnoid villi in the sagittal sinus, with limitation in the reabsorption of the CSF. Therefore, taking into account the relationship between CSF and endolaberinic fluids, we consider Hydrocephalus as a causal factor of Labyrinthic Hydrops, in our case, when hydrocephalus was resolved, recovery of microhomostasis was achieved, evidently with the disappearance of the Cocleovestibular symptomatology, therefore we conclude:

a. Endolaberinic fluids directly and indirectly contact the CSF.

b. Hydrocephalus is a disorder of cerebral fluid dynamics that can disturb the microhomostasis of the fluids of the inner ear, conditioning a labyrinthine Hydrops.

c. The RSM Cerebral is a complementary examination in the pathogenesis of the Labyrinthic Hydrops.

\section{References}

1. Carrau RL, Myers EN, Johnson JT (1990) Management of tumors arising in the parapharyngeal space. Laryngoscope 100(6): 583-589.

2. Fagan JJ, Myers EN, Barnes L (1999) A parapharyngeal myxoid liposarcoma. J Laryngol Otol 113(2): 179-182.

3. Olsen KD (1994) Tumors and surgery of the parapharyngeal space. Laryngoscope 104(5 pt 2)(suppl 63): 1-28.

4. Pensak ML, Gluckman JL, Shumrick KA (1994) Parapharyngeal space tumors: an algorithm for evaluation and management. Laryngoscope 104(9): 1170-1173.

5. Lucas DR, Nascimento AG, Sanjay BK, Rock MG (1994) Welldifferentiated liposarcoma. The Mayo Clinic experience with 58 cases. Am J Clin Pathol 102(5): 677-683. 
6. McCulloch TM, Makielski KH, McNutt MA (1992) Head and neck liposarcoma: a histopathologic reevaluation of reported cases. Arch Otolaryngol Head Neck Surg 118(10): 1045-1049.
7. Rogers J, Patil Y, Strickland-Marmol L, Padhya T (2010) Lipomatous tumors of the parapharyngeal space: case series and literature review. Arch Otolaryngol Head Neck Surg 136(6): 621-624.

\section{Your next submission with Juniper Publishers} will reach you the below assets

- Quality Editorial service

- Swift Peer Review

- Reprints availability

- E-prints Service

- Manuscript Podcast for convenient understanding

- Global attainment for your research

- Manuscript accessibility in different formats

( Pdf, E-pub, Full Text, Audio)

- Unceasing customer service

Track the below URL for one-step submission https://juniperpublishers.com/online-submission.php 